\title{
Sanger sequencing as a first-line approach for molecular \\ diagnosis of Andersen-Tawil syndrome [version 1; peer review:
}

\section{3 approved]}

\author{
Armando Totomoch-Serra (iD)1, Manlio F. Marquez (D)2, \\ David E. Cervantes-Barragán ${ }^{3}$
}

${ }^{1}$ Department of Genetics and Molecular Biology, Centro de Investigación y de Estudios Avanzados del Instituto Politécnico Nacional, Ciudad de México, Mexico

2Department of Electrophysiology, Instituto Nacional de Cardiología “Ignacio Chávez”, Ciudad de México, Mexico

${ }^{3}$ Department of Genetics, Hospital Central del Sur de Alta Especialidad PEMEX, Ciudad de México, Mexico

V1 First published: 28 Jun 2017, 6:1016

https://doi.org/10.12688/f1000research.11610.1

Latest published: 28 Jun 2017, 6:1016

https://doi.org/10.12688/f1000research.11610.1

\section{Abstract}

In 1977, Frederick Sanger developed a new method for DNA sequencing based on the chain termination method, now known as the Sanger sequencing method (SSM). Recently, massive parallel sequencing, better known as next-generation sequencing (NGS), is replacing the SSM for detecting mutations in cardiovascular diseases with a genetic background. The present opinion article wants to remark that "targeted" SSM is still effective as a first-line approach for the molecular diagnosis of some specific conditions, as is the case for Andersen-Tawil syndrome (ATS). ATS is described as a rare multisystemic autosomal dominant channelopathy syndrome caused mainly by a heterozygous mutation in the KCNJ2 gene. KCJN2 has particular characteristics that make it attractive for "directed" SSM. KCNJ2 has a sequence of 17,510 base pairs (bp), and a short coding region with two exons (exon $1=166 \mathrm{bp}$ and exon $2=5220 \mathrm{bp}$ ), half of the mutations are located in the C-terminal cytosolic domain, a mutational hotspot has been described in residue Arg218, and this gene explains the phenotype in $60 \%$ of ATS cases that fulfill all the clinical criteria of the disease. In order to increase the diagnosis of ATS we urge cardiologists to search for facial and muscular abnormalities in subjects with frequent ventricular arrhythmias (especially bigeminy) and prominent $U$ waves on the electrocardiogram.

\section{Keywords}

Sanger sequencing, Andersen-Tawil, KCNJ2, genetic testing, Next

Generation Sequencing, clinical diagnosis, mutation

\section{Open Peer Review}

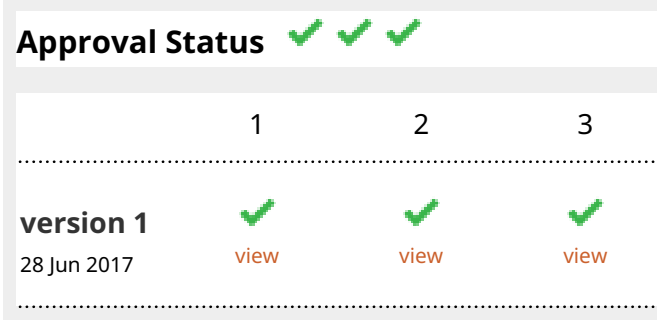

1. Oscar Campuzano ID, University of Girona,

Girona, Spain

2. Estelle Gandjbakhch, Pitie Salpêtrière University Hospital, Paris, France

3. Coeli M. Lopes, University of Rochester,

Rochester, USA

Diomedes E. Logothetis, Northeastern

University, Boston, USA

Any reports and responses or comments on the article can be found at the end of the article. 
Corresponding author: Manlio F. Marquez (manlio.marquez@gmail.com)

Competing interests: No competing interests were disclosed.

Grant information: The author(s) declared that no grants were involved in supporting this work.

Copyright: ( 2017 Totomoch-Serra A et al. This is an open access article distributed under the terms of the Creative Commons Attribution License, which permits unrestricted use, distribution, and reproduction in any medium, provided the original work is properly cited.

How to cite this article: Totomoch-Serra A, Marquez MF and Cervantes-Barragán DE. Sanger sequencing as a first-line approach for molecular diagnosis of Andersen-Tawil syndrome [version 1; peer review: 3 approved] F1000Research 2017, 6:1016 https://doi.org/10.12688/f1000research.11610.1

First published: 28 Jun 2017, 6:1016 https://doi.org/10.12688/f1000research.11610.1 


\section{Introduction}

In 1977, Frederick Sanger developed a new method for DNA sequencing based on the chain termination method, where nucleotides in a single-stranded DNA molecules are determined by complementary synthesis of polynucleotide chains, based on the selective incorporation of chain-terminating dideoxynucleotides driven by the DNA polymerase enzyme ${ }^{1}$. For this method, Sanger was awarded in 1980 with a second Nobel Prize in Chemistry, and nowadays this method is still known as the Sanger method of DNA sequencing, becoming a standard method in clinical genetics. The present opinion article wants to remark that, targeted SSM is still effective in specific clinical scenarios at a lower cost as a diagnostic method compared to new technologies for sequencing, one example is the detection of Andersen-Tawil syndrome (ATS).

\section{Next-generation sequencing: available for everyone?}

Next-generation sequencing (NGS) technology, also known as massive parallel, high throughput or deep sequencing, is gradually replacing the traditional SSM as the first choice method for screening mutations in genetic cardiovascular diseases ${ }^{2}$.

The genetic heterogeneity in long $\mathrm{QT}^{3}$ and Brugada syndromes ${ }^{4}$ has made this new genetic testing approach mandatory. The advantages of NGS versus the SSM in cases of genetic heterogeneity are undeniable, but NGS is still expensive and unaffordable for developing countries. The SSM remains the gold standard for sequencing short fragments of DNA $(<1000$ bases), previously amplified by PCR.

\section{Andersen-Tawil Syndrome: a rare disease}

ATS, also named Long QT syndrome type 7, is described in the Online Mendelian Inheritance in Man database (OMIM) as a multisystem autosomal dominant channelopathy syndrome caused by a heterozygous mutation in the KCNJ2 gene (OMIM Entry *600681) on chromosome 17q24.3. Periodic paralysis, ventricular arrhythmia, and distinctive dysmorphic features characterize it. Until 2015, the only gene thought to be affected was the potassium voltage-gated channel subfamily $\mathrm{J}$ member $2^{5}$ (the $K C N J 2$ gene), which encodes the alpha subunit protein of the Kir2.1 channel composed of tetramers ${ }^{6}$. Mutations in this gene have been reported in $60 \%$ of clinically suspected cases (which are classified as ATS type 1) ${ }^{7}$. Less than 200 cases with the KCNJ2 gene affected have been described worldwide since the discovery of the first mutations in $2001^{8,9}$. In 2014, a novel variant (c.472A $>\mathrm{G}$; p.Thr158Ala) in a second gene, KCNJ5, was associated with ATS in one Japanese patient taken from a cohort of 21 patients that had previously been screened negative for mutations in $K C N J 2$. The KCNJ5 gene protein (potassium channel Kir 3.4 protein) has an interaction with the $K C N J 2$ protein that leads to a dominant negative effect in the channel formed, related to the ATS phenotype $^{10}$. No additional cases of KCNJ5 mutations in independent series of ATS patients have been reported; the frequency of KCNJ5 mutations in ATS has to be determined in the future. With the widespread use of NGS, it is possible that in the next years we could discover new genes that explain part of the genetic heterogeneity observed in ATS, clarifying some of the $40 \%$ of clinically suspected negative cases that do not have a mutation in KCNJ2 (nowadays classified as ATS type 2) ${ }^{11}$.

\section{A special gene: $K C N J 2$}

The KCNJ2 gene has particular structural characteristics that makes it attractive for direct SSM, such as a relatively short sequence of 17,510 base pairs (bp), and a coding region with near to 5,000 bp with two exons (exon 1=166 bp and exon 2=5220 bp). Also, half of the mutations are located in the C-terminal cytosolic domain, and have a mutational hotspot in the residue $\operatorname{Arg} 218$; as we have addressed before, this gene explains the phenotype in $60 \%$ of ATS cases, fulfilling the clinical criteria.

\section{ATS in mestizo populations: the first description of ATS in the Mexican population}

Fifteen years have passed since the first family with ATS in a Mexican population was reported by Canun et al. ${ }^{12}$ Recently, a second proband was diagnosed in a different Mexican family, finding the mutation p.Arg218Trp in $K C N J 2^{13}$.

Multidisciplinary approach: a productive collaboration A multidisciplinary approach is extremely useful to study suspicious cases of hereditary sudden death syndrome. For ATS, the team must include a cardiologist, a neurologist and a clinical geneticist. It is very important that each of these physicians had expertise in the evaluation of subjects with sudden cardiac death syndrome. After a common agreement on suspicion of ATS, the whole coding region and intron boundaries of the non-coding region in $K C N J 2$ could be sequenced with the $\mathrm{SSM}^{14}$.

\section{Clinical ATS data that needs to be considered}

Phenotypically, Canun et $a l^{11}$ suggested that recognition of facial and limb dysmorphism (broad forehead, bushy eyebrows, small eyes, bulbous nose, malar and mandibular hypoplasia, crowded teeth, clinodactyly in the $5^{\text {th }}$ finger and cutaneous syndactyly in 2-3 toes) associated with ATS could help establish a correct ATS diagnosis. We believe that it is important that all cardiologists dealing with subjects with ventricular arrhythmias, specifically frequent ventricular premature beats in bigeminy, are aware of such distinctive phenotypic characteristics and also search for muscular disorders (weakness in limbs or periodic paralysis).

\section{Sanger sequencing is still a useful method}

The SSM is nearly 40 years old, and it remains a useful molecular tool for genetic testing. It has its limitations because it is timeconsuming, has limited use for long DNA fragments and is unable to detect sequences out of the region contemplated. We consider using "directed" SSM as first-line approach for 
diagnosis of suspected cases of ATS in places where NGS is not an option for genetic testing (due to low availability or high cost).

\section{Author contributions}

MFM and ATS conceptualized the article. ATS and MFM drafted the first and second version of the article. MFM, ATS and DECB review and approved the article.
Competing interests

No competing interests were disclosed.

Grant information

The author(s) declared that no grants were involved in supporting this work.

Acknowledgments

The authors are grateful to their patients.
1. Sanger $F$, Nicklen $S$, Coulson AR: DNA sequencing with chain-terminating inhibitors. Proc Natl Acad Sci U S A. 1997; 74(12): 5463-5467.

PubMed Abstract | Publisher Full Text | Free Full Text

2. Sikkema-Raddatz B, Johansson LF, de Boer EN, et al.: Targeted next-generation sequencing can replace Sanger sequencing in clinical diagnostics. Hum mutat. 2013; 34(7): 1035-1042.

PubMed Abstract | Publisher Full Text

3. AISenaidi KS, Wang G, Zhang L, et al:: Long QT syndrome, cardiovascular anomaly, and findings in ECG-guided genetic testing. IJC Heart \& Vessels. 2014; 4: 122-128. Publisher Full Text

4. Hu D, Barajas-Martínez H, Terzic A, et al.: ABCC9 is a novel Brugada and early repolarization syndrome susceptibility gene. Int J Cardiol. 2014; 171(3): 431-442. PubMed Abstract | Publisher Full Text | Free Full Text

5. Lu CW, Lin JH, Rajawat YS, et al.: Functional and clinical characterization of a mutation in KCNJ2 associated with Andersen-Tawil syndrome. J Med Genet. 2006; 43(8): 653-59.

PubMed Abstract | Publisher Full Text | Free Full Text

6. Lopes $\mathrm{CM}$, Zhang $\mathrm{H}$, Rohacs $\mathrm{T}$, et al:: Alterations in conserved Kir channel-PIP interactions underlie channelopathies. Neuron. 2002; 34(6): 933-44. PubMed Abstract | Publisher Full Text

7. Márquez MF, Totomoch-Serra A, Vargas-Alarcón G, et al:: Andersen-Tawil syndrome: a review of its clinical and genetic diagnosis with emphasis on cardiac manifestations. Arch Cardiol Mex. 2014; 84(4): 278-285. PubMed Abstract | Publisher Full Text
8. Plaster NM, Tawil R, Tristani-Firouzi M, et al: Mutations in Kir2.1 cause the developmental and episodic electrical phenotypes of Andersen's syndrome. Cell. 2001; 105(4): 511-519.

PubMled Abstract | Publisher Full Text

9. Tristani-Firouzi M, Jensen JL, Donaldson MR, et al:: Functional and clinical characterization of $K C N J 2$ mutations associated with LQT7 (Andersen syndrome). J Clin Invest. 2002; 110(3): 381-388.

PubMed Abstract | Publisher Full Text | Free Full Text

10. Kokunai Y, Nakata T, Furuta M, et al: A Kir3.4 mutation causes Andersen-Tawil syndrome by an inhibitory effect on Kir2.1. Neurology. 2014 ; 82(12): 1058-1064. PubMed Abstract | Publisher Full Text

11. Nguyen HL, Pieper GH, Wilders R: Andersen-Tawil syndrome: clinical and molecular aspects. Int J Cardiol. 2013; 170(1): 1-16. PubMed Abstract | Publisher Full Text

12. Canún S, Pérez N, Beirana LG: Andersen syndrome autosomal dominant in three generations. Am J Med Genet. 1999; 85(2): 147-56. PubMed Abstract | Publisher Full Text

13. Márquez MF, Totomoch-Serra A, Burgoa JA, et al.: Abnormal electroencephalogram, epileptic seizures, structural congenital heart diseas and aborted sudden cardiac death in Andersen-Tawil syndrome. Int J Cardiol. 2015; 180: 206-209. PubMed Abstract | Publisher Full Text

14. Ward LD, Kellis M: Interpreting noncoding genetic variation in complex traits and human disease. Nat Biotechnol. 2012; 30(11): 1095-1106. PubMed Abstract | Publisher Full Text | Free Full Tex 


\section{Open Peer Review}

\section{Current Peer Review Status:}

\section{Version 1}

Reviewer Report 16 October 2017

https://doi.org/10.5256/f1000research.12541.r26270

(C) 2017 Logothetis D et al. This is an open access peer review report distributed under the terms of the Creative Commons Attribution License, which permits unrestricted use, distribution, and reproduction in any medium, provided the original work is properly cited.

\section{Coeli M. Lopes}

Cardiovascular Research Institute, Department of Medicine, University of Rochester, Rochester, NY, USA

\section{Diomedes E. Logothetis}

Department of Pharmaceutical Sciences, School of Pharmacy, Bouve College of Health Sciences, Northeastern University, Boston, MA, USA

The opinion article by Totomoch-Serra and colleagues suggests that a "targeted" Sanger Sequencing Method (SSM) is an appropriate first-line approach to diagnose Andersen-Tawil syndrome (ATS). Although Next-Generation Sequencing (NGS) technology, especially in cases of genetic heterogeneity, is gradually replacing the traditional SSM as the method of choice for genetic testing, its high cost and unavailability often preclude its routine use, particularly in developing countries. The authors maintain that for conditions that require sequencing of short fragments of DNA ( $<1000$ bases), previously amplified by PCR, SSM remains the gold standard. In ATS, where $60 \%$ of the reported cases involve mutations of the KCNJ2 gene (that codes for the Kir2.1 channel protein) exhibiting autosomal dominant Mendelian inheritance, half the mutations are located in the C-terminal cytosolic domain with a hotspot at Arg218 (ATS type 1). Characteristic developmental abnormalities coupled to specific ventricular arrhythmias and/or muscular disorders can identify ATS patients who could then undergo SSM to identify the putative causative mutations in KCNJ2 with a potential $60 \%$ success. NGS could then be applied if the patient falls within the $40 \%$ of the cases that are not due to KCNJ2 (ATS type 2) with the hope to discover additional genes responsible for the disease and determine their frequency of occurrence. The opinion expressed by the authors is reasonable and advisable to physicians especially in cases where cost and access to NGS are problematic. Yet, it is likely a matter of time before cost and access to NGS improve and limit the choice of SSM for genetic testing. SSM has certainly served us well for the past 40 years and continues to serve us well in cases like ATS type 1 but it is inevitable that NGS will eventually make it obsolete. Until then, the authors make their case convincingly through this opinion article.

Is the topic of the opinion article discussed accurately in the context of the current literature? 
Yes

Are all factual statements correct and adequately supported by citations? Yes

Are arguments sufficiently supported by evidence from the published literature? Yes

Are the conclusions drawn balanced and justified on the basis of the presented arguments? Yes

Competing Interests: No competing interests were disclosed.

Reviewer Expertise: Electrophysiology of ion channels

We confirm that we have read this submission and believe that we have an appropriate level of expertise to confirm that it is of an acceptable scientific standard.

Reviewer Report 06 October 2017

https://doi.org/10.5256/f1000research.12541.r26267

(C) 2017 Gandjbakhch E. This is an open access peer review report distributed under the terms of the Creative Commons Attribution License, which permits unrestricted use, distribution, and reproduction in any medium, provided the original work is properly cited.

\section{Estelle Gandjbakhch}

Unité de Rythmologie, Institut de Cardiologie, Pitie Salpêtrière University Hospital, Paris, France

This opinion article by Totomoch-Serra et al.refers to the usefulness of directed sequencing of KCNJ2 by Sanger method for molecular diagnosis of Andersen-Tawil syndrome (ATS), a rare QT long syndrome associating ventricular arrhythmias, prominent $U$ wave, dysmorphic facial or skeletal features and periodic paralysis.

Sanger sequencing remains a useful method for directed sequencing of specific clinical syndromes with low genetic heterogeneity as ATS, especially in places where NGS is not accessible. In another hand, NGS is particularly useful and cost effective in inherited cardiomyopathies or channelopathies associated with high genetic heterogeneity (like dilated cardiomyopathy) or caused by mutations in larges genes (as RYR2 or TTN) where Sanger sequencing remains a long and expensive process. NGS can also be useful at second level when directed molecular diagnosis with Sanger method is negative.

In case where ATS is suspected, the approach described by the authors with directed sanger sequencing at first line followed by NGS in case of negative screening is a cost-effective approach for ATS molecular diagnosis.

I would only suggest describing in more details the clinical features (including symptoms or family 
history) suggestive of ATS diagnosis that should direct to KCNJ2 sequencing at first line. Addition of a typical ECG could also be useful for the reader. Comparison of costs between NGS and Sanger sequencing could also be interesting.

Is the topic of the opinion article discussed accurately in the context of the current literature?

Yes

Are all factual statements correct and adequately supported by citations? Yes

Are arguments sufficiently supported by evidence from the published literature? Yes

Are the conclusions drawn balanced and justified on the basis of the presented arguments? Yes

Competing Interests: No competing interests were disclosed.

Reviewer Expertise: Genetics of cardiomyopathies and channelopathies

I confirm that I have read this submission and believe that I have an appropriate level of expertise to confirm that it is of an acceptable scientific standard.

Reviewer Report 19 July 2017

https://doi.org/10.5256/f1000research.12541.r24341

(C) 2017 Campuzano 0. This is an open access peer review report distributed under the terms of the Creative Commons Attribution License, which permits unrestricted use, distribution, and reproduction in any medium, provided the original work is properly cited.

\section{Oscar Campuzano}

Department of Medical Sciences, School of Medicine, University of Girona, Girona, Spain

It is a well written manuscript focused on use of Sanger technology in genetic diagnosis. Currently, despite to NGS technology allows a cost-effective analysis of hundreds genes in a reduced time, Sanger sequencing remains as gold standard for validation of variants identified using NGS, segregation of variants in family members, and analysis of small genes, such as KCNJ2.

Is the topic of the opinion article discussed accurately in the context of the current literature?

Yes

Are all factual statements correct and adequately supported by citations? 
Yes

Are arguments sufficiently supported by evidence from the published literature? Yes

Are the conclusions drawn balanced and justified on the basis of the presented arguments? Yes

Competing Interests: No competing interests were disclosed.

I confirm that I have read this submission and believe that I have an appropriate level of expertise to confirm that it is of an acceptable scientific standard.

The benefits of publishing with F1000Research:

- Your article is published within days, with no editorial bias

- You can publish traditional articles, null/negative results, case reports, data notes and more

- The peer review process is transparent and collaborative

- Your article is indexed in PubMed after passing peer review

- Dedicated customer support at every stage

For pre-submission enquiries, contact research@f1000.com

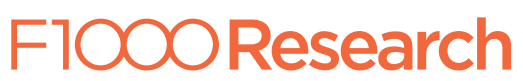

